\title{
Studies on infant mortality - Part II. Social aetiology of stillbirths and infant deaths in county boroughs of England and Wales
}

\author{
Barnet Woolf \\ (Abridged and reprinted from the British fournal of Social and Preventive Medicine \\ 1947;2:73-125.)
}

\section{INTRODUCTION}

The object of this series of papers is to give as complete and detailed a quantitative account as the data allow of the way in which infant mortality and stillbirth rates are influenced by social conditions. In the first paper (Woolf and Waterhouse, 1945) multiple regression equations were given showing the relation between the infant mortality rate and five indices of social conditions in the county boroughs of England and Wales for the eleven years 1928 to 1938 inclusive. The indices used were:

$\mathrm{H}$ : Percentage of families living more than one person per room (Census, 1931).

U: Average monthly percentage unemployment among adult males (Ministry of Labour, "Local Unemployment Index").

P: Percentage of occupied males in Social Classes IV (semi-skilled workers) and V (unskilled workers) (Census, 1931).

F: Percentage of females aged 14 and over employed in manufacture (Census, 1931).

L: Degrees of latitude north of $50^{\circ} 30^{\prime}$.

Thus $\mathrm{H}$ is an index of overcrowding, $\mathrm{U}$ and $P$ are measures of low income, $F$ is an estimate of industrial employment of mothers, and $\mathrm{L}$ is an expression of geographical position and of all the differences in social conditions associated therewith. Some thirty possible social indices were tried, and these five were selected because they seemed in combination to give the highest degree of concordance between observed infant mortality rates and those calculated from the equations. (...)

\section{INFANT MORTALITY CAUSE AND AGE AT DEATH (...)}

3. REGRESSION EQUATIONS FOR COUNTY BOROUGHS (...)

Stillbirth and infant mortality rates

All the mortality rates used for the regression equations were calculated from figures of numbers of live births, stillbirths, and infant deaths in the individual county boroughs, as published in the annual Statistical Review of the RegistrarGeneral. The death-rate from each cause group or during each period of infancy was calculated thus:

$\frac{\text { Total relevant deaths during } 1929-38 \text { inclusive }}{\text { Total live births during } 1928-38 \text { inclusive }} \times 1,000$

Stillbirth rates were also calculated per 1,000 live births, to make them comparable with the various partial infant mortality rates. (...)

Figures for death by age are given for seven subdivisions of the first year of life. These periods, are as follows:

Under 1 day

1-7 days

1-4 weeks

4 weeks -3 months

3-6 months

6-9 months

9-12 months

For death by cause, only an abridged list of causes is available, and this was revised in 1931.

Table IV Infant mortality and stillbirth rates per 1000 live births in county boroughs, 1928-38

\begin{tabular}{|c|c|c|c|c|c|c|c|}
\hline & $\begin{array}{l}\text { Unweighted } \\
\text { mean }\end{array}$ & $\begin{array}{l}\text { Weighted } \\
\text { mean }\end{array}$ & $\begin{array}{l}\text { Highest } \\
C B\end{array}$ & $\begin{array}{l}\text { Lowest } \\
C B\end{array}$ & $\begin{array}{l}\text { Total } \\
\text { deaths }\end{array}$ & $\begin{array}{l}\% \text { of IM } \\
\text { weighted }\end{array}$ & $\begin{array}{l}\% \text { of } I M+ \\
S T I\end{array}$ \\
\hline Infant mortality & 66.6 & 70.4 & 97.6 & 41.9 & 164414 & 100.0 & 61.7 \\
\hline Stillbirths & 44.5 & 43.6 & 69.7 & 32.7 & 101859 & 62.0 & 38.3 \\
\hline \multicolumn{8}{|l|}{ By cause: } \\
\hline Congential causes & 32.9 & 33.1 & 47.0 & $22 . .9$ & 77255 & 47.0 & 29.0 \\
\hline Infectious diseases & 3.9 & 4.7 & 8.2 & 1.2 & 10880 & 6.6 & 4.1 \\
\hline Bronchitis and pneumonia & 14.2 & 15.4 & 26.6 & 6.0 & 36084 & 21.9 & 13.6 \\
\hline Diarrhoea & 5.5 & 7.0 & 13.2 & 1.1 & 16424 & 10.0 & 6.2 \\
\hline Other causes & 10.0 & 10.2 & 20.5 & 5.9 & 23771 & 14.5 & 8.9 \\
\hline \multicolumn{8}{|l|}{ By age at death: } \\
\hline $0-1$ day & 10.9 & 11.1 & 15.2 & 7.4 & 25994 & 15.8 & 9.8 \\
\hline 1-7 days & 12.3 & 12.0 & 16.6 & 7.8 & 27953 & 17.0 & 10.5 \\
\hline 1-4 weeks & 9.8 & 9.8 & 16.8 & 4.4 & 22941 & 14.0 & 8.6 \\
\hline 4 weeks -3 months & 10.7 & 11.5 & 16.7 & 4.8 & 26953 & 16.4 & 10.1 \\
\hline 3-6 months & 9.3 & 10.5 & 15.9 & 4.1 & 24541 & 14.9 & 9.2 \\
\hline 6-9 months & 7.3 & 8.2 & 14.1 & 2.9 & 19211 & 11.7 & 7.2 \\
\hline 9-12 months & 6.4 & 7.2 & 11.8 & 2.9 & 16821 & 10.2 & 6.3 \\
\hline
\end{tabular}

$\mathrm{CB}=$ county borough; $\mathrm{IM}=$ infant mortality; $\mathrm{SB}=$ stillbirth 
Table VI First order correlations among social indices

\begin{tabular}{|c|c|c|c|c|c|c|}
\hline & $\begin{array}{l}\text { Male unemployment } \\
(U)\end{array}$ & $\begin{array}{l}\text { Males in social } \\
\text { classes IV } \mathscr{G} V(P)\end{array}$ & $\begin{array}{l}\text { Females employed in } \\
\text { manufacturing }(F)\end{array}$ & $\begin{array}{l}\text { Latitude north } \\
\text { of } 50^{\circ} 30^{\prime}(L)\end{array}$ & $\begin{array}{l}\text { Gross reproduction } \\
\text { rate }(G)\end{array}$ & $\begin{array}{l}\text { Population } \\
\text { density (D) }\end{array}$ \\
\hline Crowded housing $(\mathrm{H})$ & 0.6378 & 0.6870 & -0.5348 & & 0.7256 & 0.4311 \\
\hline Male unemployment (U) & - & 0.5353 & -0.0985 & 0.4743 & 0.5496 & 0.2657 \\
\hline Males in social classes IV \& V (P) & - & - & 0.0768 & 0.5015 & 0.6987 & 0.2836 \\
\hline Females employed in manufacturing $(F)$ & - & - & - & 0.2681 & -0.2404 & -0.0628 \\
\hline Latitude north of $50^{\circ} 30^{\prime}(\mathrm{L})$ & - & - & - & - & 0.3120 & 0.1447 \\
\hline Gross reproduction rate $(\mathrm{G})$ & - & - & - & - & - & 0.4244 \\
\hline
\end{tabular}

The groupings used in this paper are as follows:

The Registrar-General's category of "congenital causes, etc.," comprising all the items under the first two headings in Table I.

Infectious diseases, comprising:

Typhoid and paratyphoid fevers (called

"enteric fever" before 1931).

Measles.

Scarlet fever.

Whooping-cough.

Diphtheria.

Influenza.

Encephalitis lethargica.

Cerebrospinal fever (called "meningococcal meningitis" before 1931).

Bronchitis and pneumonia.

Diarrhoea.

Other causes, being total deaths less all those in above groups.

(...)

Some figures indicating the distribution of mortality to be accounted for by the regression equations are given in Table IV. The first column shows the mean mortality rate obtained by averaging the rates for the individual county boroughs. The next column gives the rate obtained by dividing the aggregate of deaths by the aggregate of births, which has the effect of weighting the contribution of each borough by its total of births. Where the weighted mean is larger than the unweighted, the more populous county boroughs tend to have a higher mortality rate than the smaller places, and vice versa. It will be observed that large population is positively associated with infant mortality, and negatively with stillbirths. (...)

Indices of social conditions (...)

Since the work of Woolf and Waterhouse, other possible indices have been further investigated, resulting in the computation of a fairly satisfactory measure of density of population on the site. In this paper, therefore, seven indices are used, consisting of the five employed by Woolf and Waterhouse and two new ones which will now be briefly described.

Size of family. - The measure used is G. the gross reproduction rate in 1931, as calculated by Charles (1938) from Census data. The gross reproduction rate is the computed average number of girl babies produced by a woman during the whole of her reproductive period. (...)

Density of population (...)

In the 1931 Census, figures of area and population are given for each county borough by wards and sometimes by other kinds of subareas. From these the weighted density in each borough was calculated. (...) The weighted index, as shown later, gives appreciable correlation and regression coefficients with the various components of infant mortality. Although it is probably only a rough approximation to the true average density per person as defined above, it is nevertheless a relevant index in respect of infant death rates. The weighted index of persons per acre is denoted by the symbol $\mathrm{D}$.

First order correlations among the social indices are set out in Table VI. One of the new indices, G. shows quite a high correlation with $\mathrm{H}$. Size of family is strongly associated with overcrowding in the house. The correlations with $\mathrm{P}$ and $\mathrm{U}$, though lower, are also considerable. Poverty and unemployment tend to be highest in boroughs where family sizes are above the average. The correlation with $F$ is negative, and rather small. On the whole, industrial employment of women is associated with small numbers of children. The other new index, $\mathrm{D}$, gives unexpectedly low correlations with $\mathrm{H}$ and G. Density on the site is not the same social phenomenon as overcrowding in the house or large family size. The small correlations between $\mathrm{D}$ and the other variables indicate that its inclusion in the regression equations may add appreciably to the amount of variance accounted for.

Table VII shows the first order correlations between social indices and the various mortality rates. These will be commented on later.

Methods of computation (...)

The regression constant, $\mathrm{K}$, gives the computed value of the dependent variable when each of the independent variables is at some chosen origin. Woolf and Waterhouse fixed the values of their social indices for the calculation of $\mathrm{K}$ so as to make this parameter give an estimate of the mortality rate to be expected if adverse social conditions could have been eliminated. They put $\mathrm{H}, \mathrm{U}, \mathrm{P}$, and $\mathrm{F}$ at zero, so postulating an ideal population without overcrowding, unemployment, low-paid occupations, or industrial employment of women. (...)

Since infant mortality increases with increasing latitude, they put their origin in the extreme south of England, at latitude $50^{\circ} 30^{\prime}$.

(...) The three county boroughs with the lowest values of gross reproduction rate in 1931 were: Bournemouth, 0.549; Southport, 0.594; Blackpool, 0.600. These are all seaside resorts, where the reproduction rate would have been artificially depressed by an excess of unmarried female domestic and catering workers. A reas- 
Table VII First order correlations between mortality rates and social indices

\begin{tabular}{|c|c|c|c|c|c|c|c|}
\hline & $\begin{array}{l}\text { Crowded } \\
\text { housing }(H)\end{array}$ & $\begin{array}{l}\text { Male } \\
\text { unemployment (U) }\end{array}$ & $\begin{array}{l}\text { Males in social } \\
\text { classes IV } \mathcal{E} V(P)\end{array}$ & $\begin{array}{l}\text { Females employed } \\
\text { in manufacture }(F)\end{array}$ & $\begin{array}{l}\text { Latitude north } \\
\text { of } 50^{\circ} 30^{\prime}(L)\end{array}$ & $\begin{array}{l}\text { Gross reproduction } \\
\text { rate }(G)\end{array}$ & $\begin{array}{l}\text { Population } \\
\text { density (D) }\end{array}$ \\
\hline Infant mortality & 0.7353 & 0.6651 & 0.6686 & 0.3428 & 0.6634 & 0.5655 & 0.3394 \\
\hline Stillbirths & 0.2004 & 0.4734 & 0.2989 & 0.4221 & 0.4000 & -0.0966 & -0.1981 \\
\hline \multicolumn{8}{|l|}{ Cause of death: } \\
\hline Congenital & 0.4650 & 0.4691 & 0.4821 & 0.4875 & 0.6061 & 0.2436 & -0.0134 \\
\hline Infectious disease & 0.6438 & 0.4832 & 0.5901 & 0.1956 & 0.4493 & 0.5623 & 0.5265 \\
\hline Bronchitis \& pneumonia & 0.7566 & 0.6659 & 0.6988 & 0.2299 & 0.55877 & 0.6701 & 0.3912 \\
\hline Diarrhoea & 0.6101 & 0.3554 & 0.4303 & 0.1812 & 0.3841 & 0.5529 & 0.5748 \\
\hline Other causes & 0.5171 & 0.6738 & 0.4693 & 0.1248 & 0.5896 & 0.3273 & 0.1688 \\
\hline \multicolumn{8}{|l|}{ Age at death: } \\
\hline $0-1 \mathrm{~d}$ & 0.2323 & 0.1634 & 0.1508 & 0.4265 & 0.3453 & -0.0167 & -0.1174 \\
\hline $1-7 \mathrm{~d}$ & 0.3369 & 0.4544 & 0.3632 & 0.4371 & 0.6521 & 0.0688 & -0.1940 \\
\hline $1-4 \mathrm{wk}$ & 0.6806 & 0.6298 & 0.6116 & 0.2846 & 0.586 & 0.4750 & 0.1899 \\
\hline 4 wk-3 mth & 0.6477 & 0.5818 & 0.6167 & 0.2613 & 0.5404 & 0.5560 & 0.4325 \\
\hline $3-6 \mathrm{mth}$ & 0.7465 & 0.6624 & 0.6583 & 0.1621 & 0.5547 & 0.6885 & 0.5375 \\
\hline 6-9 mth & 0.7447 & 0.6215 & 0.6929 & 0.2794 & 0.5431 & 0.6442 & 0.4812 \\
\hline $9-12 \mathrm{mth}$ & 0.7626 & 0.6171 & 0.7206 & 0.2081 & 0.5007 & 0.6947 & 0.4536 \\
\hline
\end{tabular}

onable origin for $\mathrm{G}$, as representing conditions in the wealthiest towns, would therefore be somewhere about 0.6 , and this is the origin used in this paper in the calculations of $\mathrm{K}$. For $\mathrm{D}$, the weighted density, the arbitrary figure chosen is 20 persons per acre, as representing the approximate level aimed at in good planned housing. The value of $K$ in each of the equations therefore gives the mortality rate to be expected, if the equation is a true description of the facts, in an ideal population with:

No families living more than one person per room.

No men unemployed.

No men in low-paid occupations.

No women employed in industry.

A latitude of $50^{\circ} 30^{\prime}$ of the extreme south of England.

A gross reproduction rate of 0.6 .

A weighted density of 20 persons per acre. (...)

The regression equations (...)

Tests of the statistical significance of the various equations, involving the conventional assumptions about random sampling from a normally distributed universe, are set out in Table IX. For each equation there is shown:

The coefficient of multiple correlation, denoted by $\mathbf{R}$.

The explanation, or proportion of total variance accounted for by the equation. This is of course equal to $R^{2}$, and is denoted by $E$.

The non-explanation, or residual variance, which equals $1-\mathrm{E}$.

Table IX Significances of equations

\begin{tabular}{llllll}
\hline Equation & $R$ & $E=R^{2}$ & $1-E$ & $F$ & $S E$ of estimate \\
\hline Infant mortality & 0.8960 & 0.8027 & 0.1973 & 43.0 & 6.03 \\
Stillbirths & 0.8079 & 0.6527 & 0.3473 & 19.9 & 4.51 \\
Cause of death: & & & & & \\
Congenital & 0.7920 & 0.6272 & 0.3728 & 17.8 & 3.14 \\
Infectious diseases & 0.7707 & 0.5940 & 0.4060 & 15.5 & 0.93 \\
Bronchitis \& pneumonia & 0.8781 & 0.7711 & 0.2289 & 35.6 & 2.35 \\
Diarrhoea & 0.7664 & 0.5874 & 0.4126 & 15.0 & 1.75 \\
Other causes & 0.7526 & 0.5664 & 0.4336 & 13.8 & 1.56 \\
Age at death: & & & & & \\
0-1 d & 0.5608 & 0.3145 & 0.6855 & 4.8 & 1.45 \\
1-7 d & 0.8233 & 0.6778 & 0.3222 & 22.2 & 1.27 \\
1-4 wk & 0.8301 & 0.6891 & 0.3109 & 23.4 & 1.27 \\
4 wk-3 mth & 0.8002 & 0.6403 & 0.3597 & 18.8 & 1.53 \\
3-6 mth & 0.8834 & 0.7804 & 0.2196 & 37.6 & 1.35 \\
9-12 mth & 0.8809 & 0.7759 & 0.2241 & 36.6 & 1.13 \\
\hline
\end{tabular}

$0.1 \%$ point for $\mathrm{F}=3.9$.
The value of Snedecor's F calculated for the appropriate number of degrees of freedom, according to the formula:

$$
\mathrm{FE}=\frac{74 \mathrm{E}}{7(1-\mathrm{E})}
$$

It is clear from the table that the level of explanation is high. With one exception, all values of $R$ are above 0.75 , and of $E$ above 0.56 . The exception is mortality during the first 24 hours, which would be expected to have a large error variance owing to uncertainty of timing of births and deaths. But even this equation has an $\mathrm{F}$ of 4.8 as compared with the $0.1 \%$ point of 3.9 , which means that, on the conventional assumptions, the odds are much more than 1,000 to I against the regression arising from chance fluctuations. For the other equations the $F$ values are much higher, rising to $\mathbf{4 3}$ for total infant mortality. The equations as a whole may therefore be regarded as highly significant. The reliability of the individual regression coefficients, and the extent to which the equations can be regarded as accounting for all observed mortality differences, will be discussed in a later section.

\section{SOCIAL AETIOLOGY OF STILLBIRTHS AND INFANT DEATHS}

A set of calculations (...) can be made for the country as a whole by substituting in the various equations the mean value of each social index among county boroughs. There is, of course, no question here of finding any difference between calculated and observed rates, since the value of $\mathrm{K}$ is fixed by equating these two rates when the independent variables are all at their means. The object of such computations for the aggregate of county boroughs would be to obtain estimates of the amount of mortality associated with each social index. This procedure is justified only in so far as the individual regression coefficients, as distinct from the equations as a whole, can be regarded as "significant". The discussion of this point is best deferred until after the presentation of the results. For the moment the regression coefficients will be provisionally regarded as reliable measures of the relative influence of the various social agencies on infant deaths. 
Table XI Mortality rates associated with the various social indices

\begin{tabular}{|c|c|c|c|c|c|c|c|c|c|c|}
\hline & Mean & $\begin{array}{l}\text { Regression } \\
\text { constant } \\
(K)\end{array}$ & $\begin{array}{l}\text { Over } \\
\text { crowding } \\
(H)\end{array}$ & $\begin{array}{l}\text { Male } \\
\text { unemployment } \\
\text { (U) }\end{array}$ & $\begin{array}{l}\text { Male social } \\
\text { class } I V \\
\text { or } V(P)\end{array}$ & $\begin{array}{l}\text { Females working } \\
\text { in manufacturing } \\
\text { (F) }\end{array}$ & $\begin{array}{l}\text { Latitude } \\
\text { north of } 50^{\circ} \\
30^{\prime}(L)\end{array}$ & $\begin{array}{l}\text { Gross } \\
\text { reproduction } \\
\text { rate }(G)\end{array}$ & $\begin{array}{l}\text { Population } \\
\text { density } \\
\text { (D) }\end{array}$ & $\begin{array}{l}\text { Total } \\
\text { explained }\end{array}$ \\
\hline $\begin{array}{l}\text { Infant mortality } \\
\text { Stillbirth } \\
\text { Infant mortality }\end{array}$ & $\begin{array}{l}66.60 \\
44.48\end{array}$ & $\begin{array}{l}26.81 \\
25.66\end{array}$ & $\begin{array}{l}9.82 \\
1.60\end{array}$ & $\begin{array}{r}8.64 \\
10.49\end{array}$ & $\begin{array}{r}5.46 \\
12.52\end{array}$ & $\begin{array}{l}6.13 \\
2.93\end{array}$ & $\begin{array}{l}5.12 \\
0.34\end{array}$ & $\begin{array}{r}4.02 \\
-7.52\end{array}$ & $\begin{array}{r}0.60 \\
-1.54\end{array}$ & $\begin{array}{l}39.79 \\
18.82\end{array}$ \\
\hline $\begin{array}{l}\text { \& stillbirth } \\
\text { Cause of death: }\end{array}$ & 111.08 & 52.47 & 11.42 & 19.13 & 17.98 & 9.06 & 5.46 & -3.50 & -0.94 & 58.61 \\
\hline $\begin{array}{l}\text { Congenital } \\
\text { Infection } \\
\text { Respiratory } \\
\text { Diarrhoea } \\
\text { Other } \\
\text { Total } \\
\text { Age at death: }\end{array}$ & $\begin{array}{r}32.93 \\
3.85 \\
14.24 \\
5.54 \\
9.99 \\
66.55\end{array}$ & $\begin{array}{r}19.81 \\
0.21 \\
0.03 \\
2.00 \\
4.74 \\
26.79\end{array}$ & $\begin{array}{l}2.80 \\
0.81 \\
3.24 \\
2.29 \\
0.62 \\
9.76\end{array}$ & $\begin{array}{r}3.01 \\
0.30 \\
2.89 \\
-0.36 \\
2.66 \\
8.50\end{array}$ & $\begin{array}{r}3.20 \\
1.08 \\
2.62 \\
-2.58 \\
1.23 \\
5.55\end{array}$ & $\begin{array}{l}2.75 \\
0.43 \\
1.91 \\
0.96 \\
0.16 \\
6.21\end{array}$ & $\begin{array}{l}2.36 \\
0.19 \\
0.63 \\
0.55 \\
1.31 \\
5.04\end{array}$ & $\begin{array}{r}-0.12 \\
0.45 \\
2.63 \\
1.86 \\
-0.72 \\
4.10\end{array}$ & $\begin{array}{r}-0.88 \\
0.38 \\
0.29 \\
0.82 \\
-0.01 \\
0.60\end{array}$ & $\begin{array}{r}13.12 \\
3.64 \\
14.21 \\
3.54 \\
5.25 \\
39.76\end{array}$ \\
\hline $\begin{array}{l}0-1 \mathrm{~d} \\
1-7 \mathrm{~d} \\
1-4 \mathrm{wk} \\
4 \mathrm{wk}-3 \mathrm{mth} \\
3-6 \mathrm{mth} \\
6-9 \mathrm{mth} \\
9-12 \mathrm{mth} \\
\text { Total } \\
\text { Neonatal } \\
\text { Post-neonatal }\end{array}$ & $\begin{array}{r}10.94 \\
12.33 \\
9.75 \\
10.67 \\
9.28 \\
7.26 \\
6.39 \\
66.62 \\
33.02 \\
33.60\end{array}$ & $\begin{array}{r}9.07 \\
7.45 \\
3.38 \\
3.98 \\
2.09 \\
1.34 \\
-0.27 \\
27.04 \\
19.90 \\
7.14\end{array}$ & $\begin{array}{r}1.83 \\
0.82 \\
2.08 \\
0.82 \\
1.19 \\
1.73 \\
1.57 \\
10.04 \\
4.73 \\
5.31\end{array}$ & $\begin{array}{l}0.28 \\
1.74 \\
1.38 \\
1.35 \\
1.65 \\
1.22 \\
0.90 \\
8.52 \\
3.40 \\
5.12\end{array}$ & $\begin{array}{r}-0.81 \\
1.14 \\
1.11 \\
1.58 \\
0.45 \\
-0.27 \\
2.00 \\
5.20 \\
1.44 \\
3.76\end{array}$ & $\begin{array}{l}0.81 \\
0.82 \\
0.72 \\
0.96 \\
0.89 \\
1.13 \\
0.81 \\
6.14 \\
2.35 \\
3.79\end{array}$ & $\begin{array}{r}0.45 \\
1.80 \\
1.07 \\
0.64 \\
0.74 \\
0.34 \\
-0.02 \\
5.03 \\
3.33 \\
1.70\end{array}$ & $\begin{array}{r}-0.38 \\
-0.82 \\
0.18 \\
0.91 \\
1.65 \\
1.40 \\
1.15 \\
4.09 \\
-1.02 \\
5.11\end{array}$ & $\begin{array}{c}-0.32 \\
-0.62 \\
-0.17 \\
0.43 \\
0.62 \\
0.37 \\
0.25 \\
0.56 \\
-1.11 \\
1.67\end{array}$ & $\begin{array}{r}1.87 \\
4.88 \\
6.37 \\
6.69 \\
7.19 \\
5.92 \\
6.66 \\
39.58 \\
13.12 \\
26.46\end{array}$ \\
\hline
\end{tabular}

Table XIV Mortality rates with social indices grouped into aetiological categories

\begin{tabular}{lrrrrrrr}
\hline & $\begin{array}{l}\text { Better off } \\
\text { rate }(K)\end{array}$ & $\begin{array}{c}\text { Crowding } \\
(H \text { E } P)\end{array}$ & $\begin{array}{c}\text { Poverty } \\
(U \mathcal{E} P)\end{array}$ & $\begin{array}{l}\text { Size of } \\
\text { family }(G)\end{array}$ & $\begin{array}{l}\text { Work by } \\
\text { women }(F)\end{array}$ & $\begin{array}{l}\text { Latitute } \\
(L)\end{array}$ & $\begin{array}{l}\text { Total } \\
\text { explanations }\end{array}$ \\
\hline Infant mortality & 26.81 & 10.42 & 14.10 & 4.02 & 6.13 & 5.12 & 39.79 \\
Stillbirths & 25.66 & 0.66 & 23.10 & -7.52 & 2.93 & 0.34 & 18.82 \\
Infant mortality & & & & & & \\
$\quad$ stillbirth & 52.47 & 10.48 & 37.11 & -3.50 & 9.06 & 5.46 & 58.61 \\
Cause of death: & & & & & & \\
Congenital & 19.81 & 1.92 & 6.21 & -0.12 & 2.75 & 2.36 & 13.12 \\
Infection & 0.21 & 1.19 & 1.38 & 0.45 & 0.43 & 0.19 & 3.64 \\
Respiratory & 0.03 & 3.53 & 5.51 & 2.63 & 1.91 & 0.63 & 14.21 \\
Diarrhoea & 2.00 & 3.11 & -2.94 & 1.86 & 0.96 & 0.55 & 3.54 \\
Other causes & 4.74 & 0.61 & 3.89 & -0.72 & 0.16 & 1.31 & 5.25 \\
Total & 26.79 & 10.63 & 14.05 & 4.10 & 6.21 & 5.04 & 39.76 \\
Age at death: & & & & & & \\
0-1 d & 9.07 & 1.51 & -0.53 & -0.38 & 0.81 & 0.46 & 1.87 \\
1-7 d & 7.45 & 0.20 & 2.88 & -0.82 & 0.82 & 1.80 & 4.88 \\
1-4 wk & 3.38 & 1.91 & 2.49 & 0.18 & 0.72 & 1.07 & 6.37 \\
4 wk-3 mth & 3.98 & 1.25 & 2.93 & 0.91 & 9.96 & 0.64 & 6.69 \\
3-6 mth & 2.09 & 1.81 & 2.10 & 1.65 & 0.89 & 0.74 & 7.19 \\
6-9 mth & 1.34 & 2.10 & 0.95 & 1.40 & 1.13 & 0.34 & 5.92 \\
9-12 mth & -0.27 & 1.82 & 2.90 & 1.15 & 0.81 & -0.02 & 6.66 \\
Total & 27.04 & 10.60 & 13.72 & 4.09 & 6.14 & 5.03 & 39.58 \\
Neonatal & 19.90 & 3.62 & 4.84 & -1.02 & 2.35 & 3.33 & 13.12 \\
Post neonatal & 7.14 & 6.98 & 8.88 & 5.11 & 3.79 & 1.70 & 26.46 \\
\hline
\end{tabular}

The results of the computations are set out in Table XI. For each equation there is shown, first, the mean rate for the type of mortality specified, then the $\mathrm{K}$ figure representing the expected rate among the "population" as defined above, then the increment or decrement in mortality associated with each social variable for the average county borough as compared with the baseline population used for calculating $\mathrm{K}$, and finally the total amount of mortality "explained" by the equation, which is of course the mean minus $K$.

Looking first at the columns headed "Mean", " $K$ ", and "Total explained", one notices the following features: Approximately three-fifths of the total infant mortality and two-fifths of the stillbirths are associated with the differences in social conditions between the average county borough population and the better off section. For infant mortality and stillbirths together, just over half the deaths are attributable to the specified social agencies.

Among the cause groups, almost the whole of the mortality from infectious diseases and from bronchitis and pneumonia is socially conditioned. For diarrhoea more than a third, and for other causes nearly a half, of the average mortality rate are found at the better off level. For congenital causes, $\mathrm{K}$ is about three-fifths of the mean, just as it is for stillbirths.

When mortality is dissected by age at death, the proportion explained steadily rises throughout the year of infancy. Indeed, in the fourth quarter the computed mortality for the arbitrarily chosen baseline population is -0.27 , which is, of course, not significantly different from zero. Neonatal deaths, like stillbirths and congenital causes, give a $\mathrm{K}$ about three-fifths of the mean, while in the post-natal period more than three-quarters of the deaths are associated with adverse social conditions. (...)

The data in Table XI are shown in Table XIV, with the social indices grouped into aetiological categories, and both tables should be consulted during the course of the discussion. It is reasonable to suppose that the mortality from these diseases will depend on two processes: (1) exposure to infection, which will determine the case-incidence; (2) case-fatality rate, which will vary with the stamina and resistance of the infected infants. Probability of infection will be positively associated with $\mathrm{H}$ (the crowding of the house), $D$ (the size and density of the herd), and $G$. which measures the extra risk when the 
Table XV Percentages of "explained" deaths from infectious diseases and bronchitis and pneumonia associated with the social indices

\begin{tabular}{|c|c|c|}
\hline & $\begin{array}{l}\text { Infectious diseases } \\
(\%)\end{array}$ & $\begin{array}{l}\text { Bronchitis \& pneumonia } \\
(\%)\end{array}$ \\
\hline \multicolumn{3}{|l|}{ Exposure to infection: } \\
\hline Crowded housing $(\mathrm{H})$ & 22 & 23 \\
\hline Population density (D) & 11 & 2 \\
\hline $\mathrm{H}+\mathrm{D}$ & 33 & 25 \\
\hline Gross reproduction rate $(G)$ & 12 & 19 \\
\hline $\begin{array}{l}\mathrm{H}+\mathrm{D}+\mathrm{G} \\
\text { Resistance: }\end{array}$ & 45 & 44 \\
\hline Male unemployment (U) & 8 & 20 \\
\hline $\begin{array}{l}\text { Males in social classes IV \& V }(P) \\
U+P\end{array}$ & 30 & 19 \\
\hline $\begin{array}{l}\text { Females employed in manufacturing } \\
\text { Latitude north of } 50^{\circ} 30^{\prime}\end{array}$ & $\begin{array}{r}12 \\
5\end{array}$ & $\begin{array}{r}13 \\
4\end{array}$ \\
\hline Total & 100 & 100 \\
\hline
\end{tabular}

crowding is by other children rather than adults.

Once infected, the baby's chance of survival would depend upon a number of circumstances, including: (a) its state of nutrition; (b) the quality of the care and nursing it received; and (c) its prenatal and postnatal history, and especially whether it was born prematurely.

All such effects would be quite efficiently measured by the poverty indices, $U$ and $P$. (...)

From Tables XI and XIV it will be seen that in both cause groups the contribution of the poverty indices ( $U$ and $P$ ) is rather greater than that of the crowding indices ( $\mathrm{H}$ and $\mathrm{D})$, though if $\mathrm{G}$ is included as an element in the crowding complex the order is reversed. The relative influence of the various social agencies is more clearly brought out in Table XV, where the contribution to the mean mortality of each index, as given in Table XI, is expressed as a percentage of the total explained mortality in the two cause groups. It will be seen that the indices expressing exposure to infection account for $44 \%$ and $45 \%$ of the respective mortalities, and those associated with resistance for $38 \%$ and $39 \%$.

From Tables XI and XIV one can form an estimate of the relative importance of the various social agencies with respect to the total loss of infant life. The chief indications are as follows:

1. For infant mortality, poverty, presumably mainly malnutrition, contributes about 14.1 , bulking rather larger than crowding, which is responsible for about 10.4 out of the difference between the "better off" and the mean rate.

2. In stillbirths, however, crowding is of little importance, while poverty adds about 23.0 to the rate.

3. In the $I M+S T I$ equation, measuring total reproductive wastage, poverty consequently appears nearly four times as important as housing. Elimination of malnutrition might be expected to reduce the combined mortality rate in county boroughs by about 37 units, and levelling up of housing by about 10.5 units.

4. When the other social indices are allowed for, infant mortality increases with mean family size, the negative effect in the neonatal period being more than counterbalanced by the increased risk of infection during the remainder of the period of infancy. But when infant mortality is combined with stillbirths, the net G effect is negative. If the mean family size could be increased without concomitant aggravation of overcrowding or poverty, one would expect a smaller and not a larger wastage of infant life. 5. The computed total rate at the "better off" level is about 52.5 , almost equally divided between stillbirths and infant mortality. This is less than half the observed rate of 111.1. More than half the mortality can be regarded as preventable. (...)

It must be emphasized that these aetiological deductions are not in any sense to be regarded as mathematically demonstrated. The equations show that the mortality of a county borough can be calculated, with a fairly high degree of precision, from the numerical values of its social indices. The interpretation of the equations depends not on mathematical but on social and medical considerations. The explanations sketched out above must be judged as scientific hypotheses, the criteria being:

Their internal consistency in relation to the phenomena of infant mortality.

Their degree of concordance with other independent evidence, and with clinical and social knowledge and experience.

The extent to which they throw light on observations taken from a wider field - as, for example, the pattern of mortality in London.

The extent to which they suggest profitable lines of further investigation, and are confirmed by the results of such researches.

I wish to lay special stress on the last of these criteria. It will probably have been evident all through this paper that many of the topics touched on call for special ad hoc field investigations. It may fairly be claimed that the equations as a whole do present a consistent aetiological picture, in line with other evidence. But the full validification of many of the conclusions must await further surveys and inquiries. If the statistical analysis here reported has done nothing more than place the various aetiological problems of infant death into clear perspective, directing attention to aspects amenable to field investigation, it will have been amply worth while. In their statistical study of the incidence in London of some infectious diseases of childhood, Wright and Wright (1942) say that the statistical method "may be used to test deductively the general applicability of hypotheses based upon field observations, by finding how far inferences made from relatively restricted evidence are supported by statistical findings from larger sources of data." While fully agreeing with this, I would like to draw attention to the reverse procedure - the function of statistical studies in suggesting profitable topics for field inquiries. It is only by the close interweaving of statistical and field inquiries that a true science of social medicine can be built up. It is hoped that further papers in this series will report the results of field inquiries suggested by the statistical analysis described above. (...)

5. THE BALANCE SHEET OF INFANT DEATHS (...) The balance sheet of infant deaths is shown in Table XVIII. In each category of mortality the total number of deaths in the county boroughs 
Table XVIII Balance sheet of infant deaths, county boroughs, 1928-38

\begin{tabular}{|c|c|c|c|c|c|c|c|c|c|}
\hline & $\begin{array}{l}\text { Infant } \\
\text { mortality }\end{array}$ & Stillbirths & Total & Neonatal & Postnatal & $\begin{array}{l}\text { Congential } \\
\text { causes }\end{array}$ & $\begin{array}{l}\text { Infectious diseases, } \\
\text { bronchitis and } \\
\text { pneumonia }\end{array}$ & Diarrhoea & $\begin{array}{l}\text { Other } \\
\text { causes }\end{array}$ \\
\hline $\begin{array}{l}\text { Crowding (H \& D) } \\
\text { Poverty (U \& P) } \\
\text { Size of family (G) } \\
\text { Work by mother (F) } \\
\text { Latitude (L) } \\
\text { Total explained } \\
\text { Unexplained } \\
\text { Total deaths } \\
\text { Per cent explained }\end{array}$ & $\begin{array}{l}25700 \\
32700 \\
10200 \\
16500 \\
11900 \\
97000 \\
67400 \\
164400 \\
59.0\end{array}$ & $\begin{array}{r}-1800 \\
53600 \\
-18800 \\
7800 \\
800 \\
41600 \\
60300 \\
101900 \\
40.8\end{array}$ & $\begin{array}{r}23900 \\
86300 \\
-8600 \\
24300 \\
12700 \\
138600 \\
127700 \\
266300 \\
52.0\end{array}$ & $\begin{aligned} 7200 \\
11500 \\
-2600 \\
6300 \\
7900 \\
30300 \\
46600 \\
76900 \\
39.4\end{aligned}$ & $\begin{array}{r}18500 \\
21200 \\
12800 \\
10200 \\
4000 \\
66700 \\
20800 \\
87500 \\
76.2\end{array}$ & $\begin{array}{r}3500 \\
14500 \\
-300 \\
7300 \\
5600 \\
30600 \\
46700 \\
77300 \\
39.6\end{array}$ & $\begin{array}{r}12200 \\
16100 \\
7700 \\
6200 \\
1900 \\
44100 \\
2900 \\
47000 \\
93.8\end{array}$ & $\begin{aligned} 8500 \\
-6900 \\
4700 \\
2500 \\
1300 \\
10100 \\
6300 \\
16400 \\
61.6\end{aligned}$ & $\begin{array}{r}1500 \\
9000 \\
-1900 \\
500 \\
3100 \\
12200 \\
11500 \\
23700 \\
51.5\end{array}$ \\
\hline
\end{tabular}

during the eleven year period is given, rounded off to the nearest hundred, together with the "Unexplained" deaths, the computed number that would have been expected if each social index had been at the "better off" level. The difference between the total and the unexplained deaths is divided up according to the calculated influence of the various social agencies. Thus, in the first column relating to total infant mortality, the estimate of lives that would have been saved by the elimination of crowding is 25700 ; by elimination of poverty, 32730 ; and so on. In the stillbirth column the minus signs indicate that reduction of the size of family and of crowding to the better off standard, keeping other conditions unchanged, would have been expected to lead to more deaths. But this was of course counterbalanced by the poverty index. Columns 4 and 5 give infant mortality divided into neonatal and postnatal periods. The remaining columns give cause groups. In view of the similarity of their equations, infectious diseases and bronchitis and pneumonia have been combined. Out of the 266300 stillbirths and infant deaths, 138600 , or more than half, are to be regarded as having been preventable by improvement in social conditions, and, of these, 86300 , or more than three-fifths, could have been averted by raising earnings. Over 30000 neonatal deaths and 66000 postnatal deaths are calculated to have been preventable, the latter figure including over 44000 deaths from infectious diseases and bronchitis and pneumonia.

The equations have been used to give an estimate of mortality at one postulated social level - the "better off," as defined above. They can also be employed to calculate the expected mortality of any other social stratum, as defined by arbitrarily fixed values of the social indices. Two such strata are of special interest - the poorly paid crowded section of the working class, and those living permanently at the level of pre-war unemployment relief. For the first of these, both $\mathrm{H}$ and $\mathrm{P}$ must be equated to $100 \%$, and $U$ to zero. For the second, H, P, and $U$ must each be put at $100 \%$. Plausible values must also be chosen for the other indices. The following values of the indices have been taken to define these two social levels:

"Crowded Poor"

$$
\begin{aligned}
& H=100 \\
& U=0 \\
& P=100 \\
& F=0 \\
& L=\text { Mean latitude of county boroughs } \\
& G=16 \\
& D=80
\end{aligned}
$$

"Unemployed Crowded Poor"

$\mathrm{U}=100$

All other indices as above.

The computed mortality rates at these social levels are shown in Table XIX, and compared with the "better off" figure (weighted $\mathrm{K}$ ) and the weighted mean for county boroughs. The rates for the crowded poor and the unemployed crowded poor are also shown, as percentages of the weighted mean.

It will be seen that the poor have a computed infant mortality rate of 97.8 , being 24.4 , or $39 \%$, above the mean. Owing to their postulated larger size of family, their expected stillbirth rate is 37.7 , substantially lower than the mean. Their computed total reproductive loss is $119 \%$ of the average. But the unemployed poor show both an infant mortality and a stillbirth rate of double the mean figure. The excess mortality among the poor and un-

\begin{tabular}{|c|c|c|c|c|c|c|}
\hline & \multirow[t]{2}{*}{ Better off } & \multirow{2}{*}{$\begin{array}{l}\text { Weighted } \\
\text { mean }\end{array}$} & \multirow{2}{*}{$\begin{array}{l}\text { Crowded } \\
\text { poor }\end{array}$} & \multirow{2}{*}{$\begin{array}{l}\text { Unemployed } \\
\text { crowded poor }\end{array}$} & \multicolumn{2}{|c|}{ Percentage of weighted mean } \\
\hline & & & & & $\begin{array}{l}\text { Crowded } \\
\text { poor }\end{array}$ & $\begin{array}{l}\text { Unemployed } \\
\text { crowded poor }\end{array}$ \\
\hline Infant mortality & 28.9 & 70.4 & 97.8 & 141.0 & 139 & 200 \\
\hline Stillbirths & 25.8 & 43.6 & 37.7 & 91.1 & 86 & 209 \\
\hline Infant mortality + stillbirths & 53.7 & 114.0 & 135.5 & 232.1 & 119 & 204 \\
\hline $\begin{array}{l}\text { Causes of death: } \\
\text { Congenital }\end{array}$ & 20.0 & 33.1 & 37.1 & 52.4 & 112 & \\
\hline & 0.7 & 4.7 & 9.4 & 10.9 & 201 & 234 \\
\hline $\begin{array}{l}\text { Infectuous } \\
\text { Respiratory }\end{array}$ & 0.6 & 15.4 & 28.9 & 43.6 & 187 & 283 \\
\hline Diarrhoea & 2.7 & 7.0 & 12.8 & 11.0 & 182 & 156 \\
\hline Other & 4.9 & 10.2 & 9.6 & 23.1 & 94 & 227 \\
\hline Neonatal & 19.9 & 32.9 & 36.6 & 53.8 & 111 & 164 \\
\hline Postnatal & 9.0 & 37.5 & 61.2 & 87.2 & 163 & 233 \\
\hline
\end{tabular}
employed poor occurs chiefly in the postnatal period and in the infectious and bronchitis and pneumonia cause groups. In the category of other causes, extreme poverty, as measured by $\mathrm{U}$. has the effect of doubling the computed

Table XIX Estimated mortality rates in crowded poor and unemployed crowded poor strata of population 
rate. Bronchitis and pneumonia, and to a lesser extent infectious diseases and congenital causes, also show a material rise with increase in degree of poverty. (...)

The big differences between the computed mortality rates for the "crowded poor" and the "unemployed crowded poor" is noteworthy. It indicates that, below a given level, small decreases in income, involving depreciation in the level of nutrition and other human needs, have disproportionately large effects in increasing mortality, and presumably also in adversely affecting the physique and stamina of the survivors. Conversely, any effort at social betterment may be expected to have the greatest effect in reducing mortality and morbidity if it is preferentially applied to raising the standards of the most unfortunate section of the population. The difference between the last two columns in Table XIX is a sufficient explanation of the dramatic reduction in stillbirth and infant mortality rates during the war, when limited resources were so used as to reduce the pre-war disparity in satisfaction of biological needs among the different income grades of the population.

It is important to bear in mind the limitations of the regression method as well as its powers. The equations can take cognizance only of differences between places. Any relevant circumstances that affect all places more or less equally cannot enter into the calculations. Since 1900 , infant mortality has fallen by about twothirds - from round about 150 to round about 50. But the relative disparity between the best and the worst places, or between the social classes, has remained remarkably steady. The equations can display how, at one particular period, differences in mortality rates are bound up with variations in social conditions. They cannot directly deal with the effect of the changing social background in lowering the level of mortality for rich and poor alike. The high degree of statistical explanation afforded by the equations indicates that, at any given general level of social, cultural, and sanitary progress, the differences in mortality between different strata of the population are largely conditioned by disparities in material environment, using that word in its broadest sense, and could presumably be diminished by levelling up of social conditions. But social agencies that must have affected the general level of mortality at different times, such as improvements in medical and social services, in education and nutrition and mothercraft, and possible biological changes in infective agents of disease, cannot appear in the equations directly. In this paper an attempt has been made, by comparisons between county boroughs and other types of area, to obtain some estimate of the potency of these general social agencies. It is beyond question that conscious social effort, whether direct as in maternity and child welfare services, or indirect as in universal education, has played a major part in diminishing loss of infant life, and that there is scope for further improvement in the future. But there is also abundant evidence that, at any given time in the past, variations from the general level of mortality were associated with crowding, malnutrition, industrial employment of women, and size of family, with relative effects qualitatively if not quantitatively similar to those obtaining in county boroughs during 1928-38. In this sense the equations have a validity outside the places and period to which they primarily relate. To reduce infant mortality to the unavoidable minimum it is necessary both to improve the general social, medical, and sanitary background and to ensure to each mother and baby the best possible material chance by levelling up social and economic conditions. For the immediate future, it is probable that the equations are a fairly reliable quantitative guide to the degree of reduction in infant deaths to be expected by alteration of this or that feature of the social environment. Similar equations calculated ten or twenty years hence might give different values to the coefficients associated with each social agency. But so long as disparities exist in environment at different social levels, it seems likely that there will continue to be differences in mortality rates bound up with variations in standards of housing, nutrition, and other relevant conditions, acting for each category of mortality in the direction indicated by the regression equations.

Baird D. (1945). J. Obstet. Gynaec. Brit. Emp., 52, 217, 339. Burns CM. (1942). Infant and Maternal Mortality Durham. Charles E. (1938). Article in Political Arithmetic, ed. Hogben L. London.

Cheeseman EA, Martin WJ and Russell WT. (1939). J. Hyg., Camb., 39, 181.

Crosse VM. (1945). The Premature Baby, London.

Cruickshank R. (1945). Arch. Dis. Childh., 20, 145.

Ebbs JH, Tisdall FF and Scott WA. (1941). J. Nutrit., 22, 515. Fisher RA. (1940). Ann. Eugen., 10, 422.

Halliday JL. (1928). Med. Res. Cncl. Sp. Rep. Ser., No. 120. London.

Orr JB, et al. (1943). Infant Mortality in Scotland, H.M.S.O., Edinburgh.

Registrar-General. All references give date to which report refers, not date of publication. Abbreviations: A.R., Annual Review; D.S., Decennial Supplement (Occupational Mor-
tality), Text, Text Volume of Annual Review.

Spence JC. (1933). Annual Report, Min. of Health, 214. London.

Theobald GW. (1946). J. Obstet. Gynaec. Brit. Emp., 53, 17. oodbury RM. (1925). Causal Factors in Infant Mortality, Children's Bureau, Washington.

Woolf B. and Waterhouse J. (1945). J. Hyg., Camb., 44, 67. Wright GP. and Wright HP. (1942). Ibid., 42, 451. (1945). Ibid., 44, 15.

Young, J. (1945). Med. Off., 74, 119; 127. 